CAMILA RÍOS

ESCUELA DE DISEÑO

FACULTAD DE ARQUITECTURA, DISEÑO

Y ESTUDIOS URBANOS

PONTIFICIA UNIVERSIDAD CATÓLICA

SANTIAGO, CHILE

CARIOS1@UC.CL

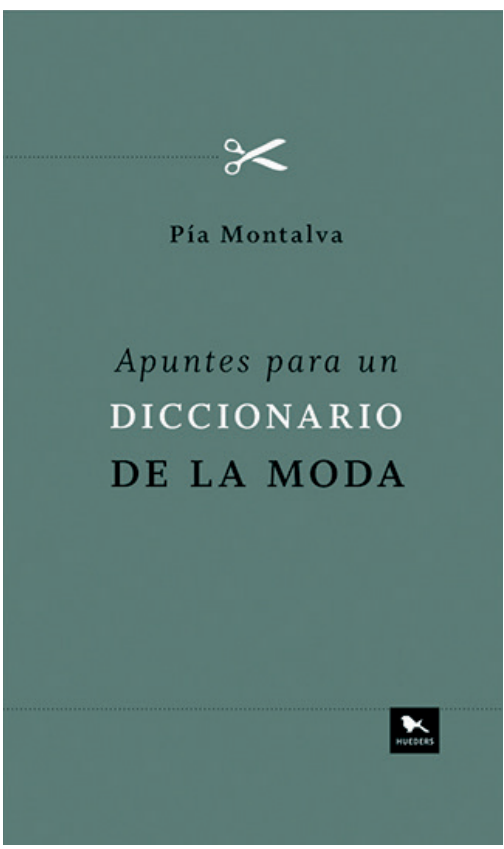

Título: Apuntes para un diccionario de la moda.

Autora: Pía Montalva

Editorial: Hueders

Número de páginas: 348 p

Año publicación: 2017

ISBN: 9789563650587

Cómo citar: Ríos, C. (2018)

Coherencia y contradicción entre

la indumentaria y el poder

RChD: creación y pensamiento, 3(4), 1-2.

DOI: 10.5354/0719-837X.2018.50296

Revista Chilena de Diseño,

RChD: creación y pensamiento

Universidad de Chile

2018, 3(4)

http://rchd.uchile.c

\section{Coherencia y contradicción entre la indumentaria y el poder}

\author{
Coherence and contraddiction between clothing and power
}

Desde una dimensión experimental, Pía Montalva nos cautiva con Apuntes para un diccionario de la moda, una publicación que circula entre definiciones autorrepresentativas y relatos de coyuntura, cargados de historia y un imaginario colectivo innegable. Conceptos comunes que apelan a nuestra cultura popular y se impregnan de personalidad a través de interesantes historias. "No, me gusta. Es parte de la religión, los que tienen miedo se van antes", responde Charly García cuando le preguntan si le da miedo vivir así, luego de una serie de eventos en clínicas de desintoxicación. En 2009, Charly García se reinventa completamente desde una rehabilitación interna, hasta una nueva construcción de apariencia que contempla el cambio de sus ajustados jeans y sus poleras de algodón desbocadas. "Charly ya no era el de antes, se había esfumado su esquelético glamour", analiza Pía Montalva, deshilvanando cada una de sus piezas textiles.

Cada crónica de estos personajes de poder, a veces confidenciales y dramáticas, son acompañadas por un concepto o elemento asociado a la indumentaria y de significación transversal: Collar de perlas, Denim, Lujo, Poncho, Suéter. Todos los conceptos son socialmente conocidos, pero en lo cotidiano, están disociados de un análisis histórico, evolutivo y de relación con la influencia y el poder. Pía Montalva describe cada elemento detalladamente, primero con una mirada técnica, para luego poner atención en la historia de la pieza y su evolución, dando un vuelco a esta cotidianeidad. Cada término es delicadamente escogido, para luego develar identidades que recaen en personas de renombre.

"¿Quién es esa mina, con esa pinta de sirvienta? ¿Qué hace acá?". Es una de las frases que evidencia la autora para dar cuenta de la significación social y cultural que se obtiene a partir del atuendo y cual es su relación con el dominio de clases. Hace referencia a un comentario textual de Julio Mahárbiz, asesor de la comisión organizadora del Festival de Cosquín (1965) al momento de ver a Mercedes Sosa subirse al escenario con su clásica indumentaria referencial a Latinoamérica. El cuidadoso valor testimonial que poseen los textos de la autora realzan la humanización de los personajes en cuestión, activando relaciones y recuerdos personales que el lector pueda tener. Invita a la indagación y profundización, estimulando la curiosidad por aspectos no descritos en el texto y que finamente nutren el relato. Este valor se complementa con una detallada descripción de la indumentaria y su uso en determinado contexto, pequeños gestos que nos ayudan a acercarnos al relato. Las texturas del material, el lustre textil, las proporciones de color, el calce de una prenda, son los detalles que revelan la autobiografía de las personas, vinculándose automáticamente a distintos cánones de apariencia relacionados con personas influyentes.

"Terno cruzado de anchas solapas y suave material acompañado de camisa blanca y corbata de seda con vistosos dibujos equilibradamente sicodélicos. Los mismos del pañuelo que asomaba apenas por el bolsillo superior de la chaqueta". Es como ella describe el vestuario de Salvador Allende a la espera de Fidel Castro a Chile, quien se caracterizó por tener especial cuidado en su apariencia e ir modificando su vestimenta sutilmente según la ocasión, 
siendo conocido como "pije", concepto chileno utilizado para describir a una persona "elegante". Denominaciones locales potencian la apropiación del texto desde la comprensión de términos propios de nuestra cultura.

Este libro, desde su novedosa estructura, articula una nueva mirada de la coherencia que significa vestirse de cierta manera en entornos de influencia, la cual, a veces inexistente, erige una identidad.

Asímismo la autora, a lo largo de sus publicaciones, desmitifica la "moda" disociada a conceptos de historia dura, resaltando su esencia inherente. Montalva contribuye al imaginario popular asociado a los textiles y su relación con el cuerpo, así como también aporta a la valoración del significado de los códigos que revelamos, concientizando el vínculo inevitable existente entre la vestimenta y lo que somos. 